\section{Seasonal changes of androgen receptor, estrogen receptors and aromatase expression in the medial preoptic area of the wild male ground squirrels (Citellus dauricus Brandt)}

\author{
F. Zhang, J. Wang, Y. Jiao, L. Zhang, \\ H. Zhang, X. Sheng, Y. Han, Z. Yuan, \\ Q. Weng \\ College of Biological Science and \\ Technology, Beijing Forestry University, \\ China
}

\section{Abstract}

The wild ground squirrel is a typical seasonal breeder. In this study, using RT-PCR, western blot and immunohistochemistry, we investigated the mRNA and protein expressions of androgen receptor (AR), estrogen receptors $\alpha$ and $\beta$ (ER $\alpha$ and $E R \beta)$ and aromatase cytochrome P450 (P450arom) in the medial preoptic area (MPOA) of hypothalamus of the wild male ground squirrel during the breeding season (April), the non-breeding season (June) and pre-hibernation (September). AR, $\mathrm{ER} \alpha, \mathrm{ER} \beta$ and P450arom protein/mRNA were present in the MPOA of all seasons detected. The immunostaining of AR and ER $\alpha$ showed no significant changes in different periods, whereas ER $\beta$ and P450arom had higher immunoreactivities during the breeding season and pre-hibernation when compared to those of the non-breeding season. Consistently, both the protein and mRNA levels of P450arom and ER $\beta$ were higher in the MPOA of pre-hibernation and the breeding season than in the non-breeding season, whereas no significant difference amongst the three periods was observed for AR and ER $\alpha$ levels. These findings suggested that the MPOA of hypothalamus may be a direct target of androgen and estrogen. Androgen may play important regulatory roles through its receptor and/or the aromatized estrogen in the MPOA of hypothalamus of the wild male ground squirrels.

\section{Introduction}

Estrogen and androgen hormones play important roles in brain sexual differentiation and sexual behavior of the vertebrates. ${ }^{1}$ The effects of androgens are mediated by androgen receptor (AR) to regulate target gene tran- scription. ${ }^{2}$ In brain, AR is closely related to male reproductive behavior, and especially in wild seasonal breeding animals AR often has emerged in seasonal variation. ${ }^{3}$ In addition, androgens can be converted to estrogens by aromatase cytochrome P450 (P450arom), which could potentially change the local estrogen levels. ${ }^{4}$ P450arom is found in various tissues in both females and males, thus estrogens are produced not only in gonads but also in extra-gonadal localizations such as bone, ${ }^{4}$ brain, ${ }^{5}$ adipose tissue, ${ }^{6}$ breast, ${ }^{7}$ and skin. ${ }^{8}$ In brain, by regulating the local estrogen levels, P450arom participates in the sexual differentiation ${ }^{9}$ of brain regions involved in the control of gonadotropin secretion and sexual behavior. ${ }^{10}$

By binding to its two nuclear estrogen receptors, estrogen receptor alpha $(\mathrm{ER} \alpha)^{11}$ and beta $(\operatorname{ER} \beta),{ }^{12}$ estrogen influences a wide range of biological activities, which is not merely restricted to the development of the reproductive and endocrine systems. ${ }^{13,14}$ In brain, ER $\alpha$ and ER $\beta$ are abundantly expressed in the hypothalamus. ${ }^{15}$ The expression levels of ER $\alpha$ and ER $\beta$ in hypothalamus are closely related to the reproductive status. ${ }^{16} \mathrm{AR}$ and $\mathrm{P} 450$ arom are highly expressed in hypothalamus and limbic system in mammals as well..$^{15,17,18}$ In the medial preoptic area (MPOA) of hypothalamus, a reproduction-related area that primarily controls male sexual behavior, ${ }^{19,20}$ co-expression of AR, ERs and P450arom has been found. ${ }^{15,17,18}$ Meanwhile, the expression of P450arom in the MPOA indicates that androgens may as well be converted into estrogens to regulate hypothalamic function and male sexual behavior. The MPOA P450arom expression and its involvement in the regulation of reproductive behavior of many vertebrates has been demonstrated, including mammals, ${ }^{21}$ birds, ${ }^{22}$ reptiles ${ }^{23}$ and fish. $^{24}$

The wild ground squirrel (Citellus dauricus Brandt) is a typical long-day seasonal breeder whose annual life cycle can be roughly divided into the breeding season (April to May), the non-breeding season (June to September) and hibernation (October to the following March). Our previous studies have found that testicular morphology and function of the wild male ground squirrels gone through robust changes throughout the year, which correlate nicely with the expression profiles of AR, ERs and P450arom. ${ }^{25}$ Interestingly, unlike other known seasonal breeding rodents, the wild ground squirrels in September, namely pre-hibernation, already show a rise in testosterone level from the non-breeding season, accompanied by revitalized spermatogenesis. ${ }^{26,27}$ To understand the potential impact of androgens and estrogens on hypothalamic function, the present study investigated the expressions of AR, $\mathrm{ER} \alpha, \mathrm{ER} \beta$ and P450arom in the MPOA of the
Correspondence: Dr. Qiang Weng, Laboratory of Animal Physiology, College of Biological Sciences and Biotechnology, Beijing Forestry University, Beijing 100083, China.

Fax: +86.10 .62336399 .

E-mail: qiangweng@bjfu.edu.cn

Key words: AR; ER $\alpha$; ER $\beta$; ground squirrel; MPOA; P450arom.

Conflict of interest: the authors declare no conflict of interest.

Funding: this study is supported by a Grant-in-Aid from Beijing Natural Science Foundation (8142029) and National Natural Science Foundation of China (NSFC, No.J1310005).

Contributions: FZ, JW, HZ, YJ participation in experiments performing, data analysis, manuscript drafting; FZ, LZ, JW, XS assistance to sample collection and experiments, participation in manuscript revision; YH, ZY, QW, study design and supervision, manuscript revision. All authors read and approved the final version.

Received for publication: 12 January 2016. Accepted for publication: 11 April 2016.

This work is licensed under a Creative Commons Attribution-NonCommercial 4.0 International License (CC BY-NC 4.0).

(C) Copyright F. Zhang et al., 2016

Licensee PAGEPress, Italy

European Journal of Histochemistry 2016; 60:2621 doi:10.4081/ejh.2016.2621

male wild ground squirrels during the breeding season, the non-breeding season and prehibernation.

\section{Materials and Methods}

\section{Animals}

The wild male ground squirrels that were regarded as adults according to their body weights (242-412 g) were captured on September $27^{\text {th }}$ of 2013 in the pre-hibernation period $(n=18)$, on April $20^{\text {th }}$ after emergence from hibernation in the breeding period $(\mathrm{n}=15)$ and on June $9^{\text {th }}$ of 2014 in the nonbreeding period $(n=16)$ in Hebei Province, China.

All the procedures on animals were carried out in accordance with the Policy on the Care and Use of Animals by the Ethical Committee, Beijing Forestry University and approved by the Department of Agriculture of Hebei province, China (JNZF11/2007). For the brain samples for immunohistochemistry, wild ground squirrels were weighed and deeply anesthetized with sodium pentobarbital solu- 
tion $(30 \mathrm{mg} / \mathrm{kg})$ and then perfused transcardially with $150 \mathrm{~mL}$ of $0.9 \%$ saline, followed by $250-300 \mathrm{~mL}$ of $4 \%$ paraformaldehyde $\left(37^{\circ} \mathrm{C}\right)$ in $0.1 \mathrm{M}$ PBS ( $\mathrm{pH}$ 7.3). Then the brain samples were postfixed for $12 \mathrm{~h}$ at room temperature in $4 \%$ paraformaldehyde and cryoprotected in $20 \%$ sucrose in $0.1 \mathrm{M}$ PBS and stored at $4^{\circ} \mathrm{C}$ until processed. Brain sections of the MPOA were cut coronally into 7-10 $\mu \mathrm{m}$ for immunohistochemistry. ${ }^{28,29}$ Otherwise the brain samples were dissected, snap frozen in liquid nitrogen and then kept in $-80^{\circ} \mathrm{C}$ for protein and mRNA detections.

\section{Immunohistochemistry}

The serial sections of brain tissues were incubated with $10 \%$ normal goat serum to reduce background staining caused by the second antibody. The sections were then incubated with primary antibodies (1:1000) raised against rabbit polyclonal anti-AR (sc-816, Santa Cruz Biotechnology, Santa Cruz, CA, USA), rabbit polyclonal anti-ER $\alpha$ (sc-542, Santa Cruz Biotechnology), rabbit polyclonal anti-ER $\beta$ (sc-8974, Santa Cruz Biotechnology) and rabbit polyclonal anti-aromatase (ab18995, Abcam, Cambridge, MA) for $12 \mathrm{~h}$ under $4^{\circ} \mathrm{C}$. The sections were then incubated with a secondary antibody, goat anti-rabbit lgG conjugated with biotin and peroxidase with avidin, using rabbit ExtrAvidin ${ }^{\mathrm{TM}}$ Peroxidase staining kit (Sigma Chemical Co., St. Louis, MO, USA) was performed, followed by visualizing with 30 mg 3,3-diaminobenzidine (Wako, Tokyo, Japan) solution in $150 \mathrm{ml}$ of $0.05 \mathrm{Mol}$ Tris- $\mathrm{HCl}$ buffer, pH 7.6, plus $30 \mu \mathrm{H}_{2} \mathrm{O}_{2}$. The specificity of AR, ER $\alpha, E R \beta$ and P450arom antibodies has been described in our previous studies. ${ }^{25,30}$ The control sections were treated with normal rabbit serum instead of the primary antisera.

\section{Immunohistochemistry score}

The score assay protocol for immunohistochemistry was adapted from previous reports. ${ }^{31,32}$ In general, the immunohistochemical localization was scored in a semiquantitative fashion incorporating both the intensity and distribution of specific staining. The intensity of specific staining was characterized as no present $(0)$, weak but detectable above control (1), distinct (2), and very strong (3). For each observed tissue component, a summary value we refer to as $\mathrm{H}$-Score was calculated. This consists of a sum of the percentages of positively stained cells multiplied by a weighted intensity of staining $\mathrm{H}-\mathrm{Score}=\Sigma \mathrm{P}_{\mathrm{i}}(\mathrm{i}$ +1 ), where $i$ is the percentage of stained cells in each intensity category, and $i$ is the intensity for $\mathrm{i}=1,2,3$. A total $\mathrm{H}$-Score for the tissue section was derived as the sum of the component H-Scores weighted by the fraction of each component observed in the tissue section.

\section{Western blotting}

Tissue extraction was done via $50 \mu \mathrm{m}$ coronal slices on a cryostat, where tissue punches (1 $\mathrm{mm}$ in diameter) were taken bilaterally throughout the MPOA, and stored in at $-80^{\circ} \mathrm{C} .^{28,29}$ Tissues was homogenized in a homogenizer containing $300 \mu \mathrm{L}$ of $10 \mathrm{mg} / \mathrm{mL}$ PMSF stock and incubated on ice for $30 \mathrm{~min}$ to maintain the temperature at $4^{\circ} \mathrm{C}$ throughout all the procedures. Following centrifugation at $12,000 \times \mathrm{g}$ for $10 \mathrm{~min}$ at $4^{\circ} \mathrm{C}$, the supernatant was collected. Protein extracts $(25 \mu \mathrm{g})$ were mixed with an equal volume of $2 \times$ Laemmli sample buffer. Equal amounts of each sample were loaded and run on a $12 \%$ SDS-PAGE gel at $18 \mathrm{~V} / \mathrm{cm}$ and transferred to nitrocellulose membranes using a wet transblotting apparatus (Bio-Rad, Richmond, CA, USA). Membranes were blocked with $3 \%$ BSA for $1 \mathrm{~h}$ at room temperature. The membranes were washed and incubated with a 1:1000 primary antibody for overnight. Secondary incubation of the membrane was then carried out using a 1:1000 dilution of goat anti-rabbit IgG tagged with horseradish peroxidase for $60 \mathrm{~min}$. Finally, the membrane was washed in $25 \mathrm{ml}$ TBS-T buffer (0.02 M Tris, $0.137 \mathrm{M} \mathrm{NaCl}$ and 0.1\% Tween-20, $\mathrm{pH}$ 7.6) plus $3 \mu \mathrm{H}_{2} \mathrm{O}_{2}$ and checked with Odyssey infrared imaging system. Preabsorptions of the antibodies were performed with an excess of relative antigens (Sigma) for the negative control. $\beta$-actin was selected as the loading control. The bands were quantified using Quantity One Software (Bio-Rad Laboratories, Inc., ver. 4.5) and the related expression ratios to $\beta$-Actin were calculated.

\section{RT-PCR}

The first-strand cDNA from total RNA was synthesized using StarScript II Reverse Transcriptase and Oligo (dT)18 by TIANScript RT Kit (Tiangen, Beijing, China). The $20 \mu \mathrm{L}$ of reaction mixture contained $3 \mu \mathrm{g}$ of total RNA, $1 \mu \mathrm{L}$ of Oligo (dT)18, $1 \mu \mathrm{L}$ of $10 \mathrm{mM}$ deoxyribonucleoside triphosphate (dNTP), $4 \mu \mathrm{L}$ of
$250 \mathrm{mM}$ Tris- $\mathrm{HCl}$ (pH 8.3), $375 \mathrm{mM} \mathrm{KCl}$ and 15 $\mathrm{mM} \mathrm{MgCl}, 2 \mu \mathrm{L}$ of $0.1 \mathrm{M}$ dithiothreitol, $0.5 \mu \mathrm{L}$ of RNase Inhibitor and $200 \mathrm{U}$ of StarScript II enzyme. The $25 \mu \mathrm{L}$ of reaction mixture contained $2 \mu \mathrm{L}$ of first-strand cDNA, $0.5 \mu \mathrm{M}$ each primer, $1.5 \mathrm{mM} \mathrm{MgCl}_{2}, 0.2 \mathrm{mM}$ dNTP, $20 \mathrm{mM}$ Tris-HCl (pH 8.4) and 2.5 U of Taq polymerase (Tiangen). The amplification was under the following condition: $94^{\circ} \mathrm{C}$ for $3 \mathrm{~min}$ for the initial denaturation of the RNA cDNA hybrid, 35 cycles of $94^{\circ} \mathrm{C}$ for $30 \mathrm{~s}, 51^{\circ} \mathrm{C}$ for $30 \mathrm{~s}$ and $72^{\circ} \mathrm{C}$ for $1 \mathrm{~min}$ with a final extension of $10 \mathrm{~min}$ at $72^{\circ} \mathrm{C}$. The first-strand cDNA was used for PCR amplification with the following primers (Table 1). The PCR product was electrophoresed in the $1 \%$ agarose gel and individual bands were visualized by ethidium bromide (EB) staining. The housekeeping gene Actb was selected as the endogenous control. The bands were quantified using Quantity One software and the related expression relative to $A c t b$ were calculated.

\section{Statistical analysis}

Statistical comparisons were made with the one-way ANOVA followed by Turkey's test. A value of $\mathrm{P}<0.05$ was considered indication of statistical significance.

\section{Results}

\section{Immunolocalization of AR, ER $\alpha$, $E R \beta$ and P450arom in the MPOA of hypothalamus}

Immunohistochemical staining of AR, ER $\alpha$, ER $\beta$ and P450arom was performed in the MPOA of the male wild ground squirrels during the breeding season, non-breeding season and pre-hibernation (Figure 1). Strong positive signal of AR was localized in the nucleus in the MPOA throughout all periods (Figure $1 \mathrm{a}-\mathrm{c}$ ). Similar observations were seen for $\mathrm{ER} \alpha$ and ERb (Figure $1 \mathrm{~d}-\mathrm{i}$ ). P450arom was present in the cytoplasm of the MPOA of the breeding

Table 1. Oligonucleotide primers used for RT-PCR.

\begin{tabular}{llc} 
Gene & Sequence of primer $\left(5^{\prime}-3^{\prime}\right)$ & Product sive (bp) \\
AR & F: CATGGCAAACACCATGAGTC & \\
& R: ATGTCCTGGAAGCATTGAG & 224 \\
$E R$ & F: TGCACCATTGACAAGAACCG & 541 \\
\hline$E R$ & R: TCCAGGAGCAAGTTAGGAGC & 215 \\
CYP19 & F: TCTGGGTGATTGCGAAGAGT & \\
& R: CCCCGAGATTGAGGACTTGT & 333 \\
$\beta$ - actin & R: CAGAAAGGCATCATATTTAACA & \\
& F: GACTCGTCGTACTCCTGCTT & 223 \\
\hline
\end{tabular}



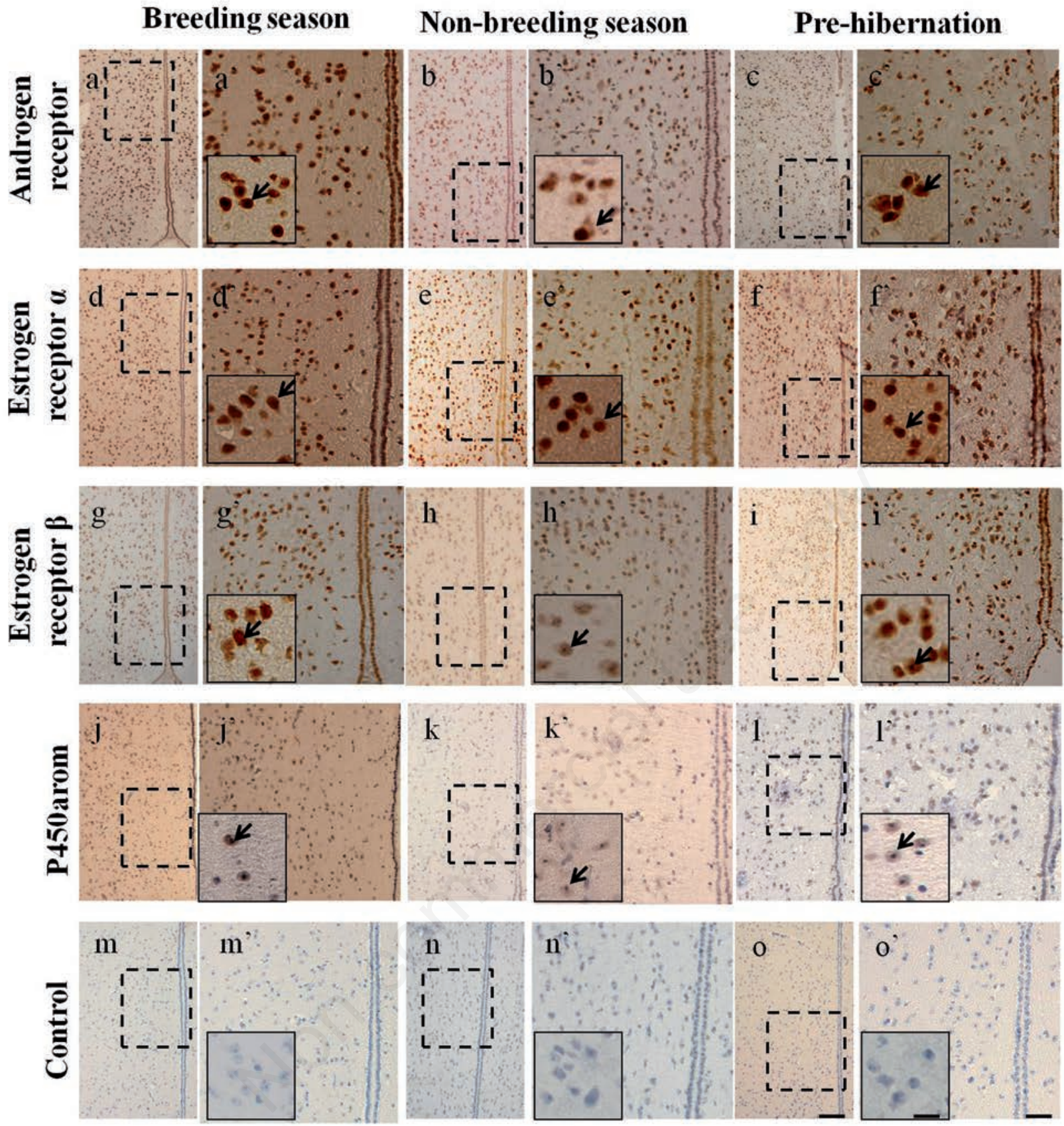

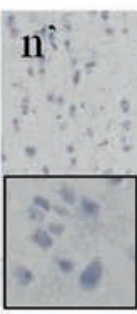

$\mathrm{C}$
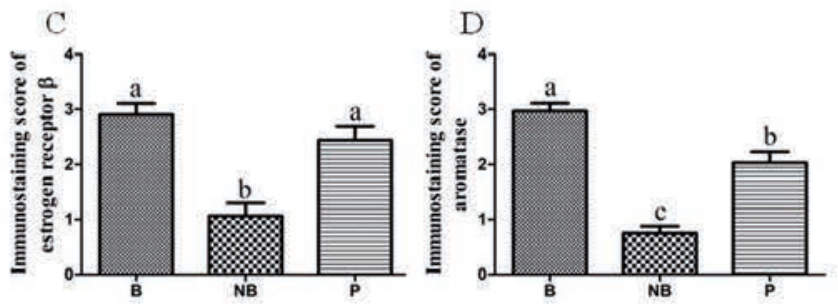

Figure 1. Immunohistochemistry of AR, ER $\alpha, \mathrm{ER} \beta$ and P450arom in the MPOA of hypothalamus of the wild male ground squirrels during the breeding season, the non-breeding season and pre-hibernation. $x^{\prime}$ is the magnification of the dashed-line square in $x$. In the boxed area on the bottom left in $x^{\prime}$, immunoreactive cells (arrow) are shown at higher magnification. Bar in $x, 100 \mu \mathrm{m}$; bar in $x^{\prime}$, $40 \mu \mathrm{m}$; bar in the boxed area, $20 \mu \mathrm{m}$ ( $\mathrm{x}$ applies from a to o). The left column $(\mathrm{a}, \mathrm{d}, \mathrm{g}, \mathrm{j}, \mathrm{m})$ represents staining in the breeding season; the center column $(b, e, h, k, n)$, and the right column $(c, f, i, l, o)$ represent immunostaining in the non-breeding season and pre-hibernation, respectively. The immunopositivity for $A R(a-c), E R \alpha(d-f)$ and $\operatorname{ER} \beta$ (g-i) was observed in the nucleus, while the immunopositivity for aromatase $(\mathrm{j}-\mathrm{l})$ was in the cytoplasm. Negative controls $(\mathrm{m}-\mathrm{o})$ were counterstained with haematoxylin. The immunostaining score of $A R(A), E R \alpha(B), E R \beta(C)$ and P450arom (D) showed the differences during the breeding season, the non-breeding season and pre-hibernation. $B$, the breeding season; NB, the non-breeding season; $P$, pre-hibernation. Bars represent means \pm SD for five independent experiments. Means within the columns marked with different letters indicate significant difference $(P<0.05)$. 
season, the non-breeding season and prehibernation (Figure $1 \mathrm{j}-\mathrm{l}$ ). No signal was observed in the negative controls (Figure $1 \mathrm{~m}$ o).

\section{Expression of AR, ER $\alpha, E R \beta$ and P450arom proteins}

Western blot analysis of proteins extracted from the MPOA of hypothalamus tissues revealed the immunoreactivities of AR, ERa, $\mathrm{ERb}$ and P450arom proteins positioned at 101 $\mathrm{kDa}, 66 \mathrm{kDa}, 59 \mathrm{kDa}$ and $55 \mathrm{kDa}$ in different seasons, respectively (Figure 2). The results were normalized to the expression level of $\beta$ - actin. While AR and ERa expression levelsshowed no significant difference amongst the three seasons (Figure $2 \mathrm{~A}, \mathrm{~B}$ ), the expression of P450arom and ERb in the breeding season and pre-hibernation were significantly higher than the non-breeding season (Figure 2 C,D).

\section{Expression of $A R, E R \alpha, E R \beta$ and P450arom mRNA}

AR, ERa, ERb and P450arom mRNA levels were also detected in the MPOA of the wild male ground squirrels during the breeding season, the non-breeding season and pre- hibernation (Figure 3). In keeping with the protein levels, AR and ER $\alpha$ mRNA expressions remained relatively stable throughout the breeding season, the non-breeding season and pre-hibernation (Figure 3 A,B). The expressions of ER $\beta$ and P450arom genes peaked in the breeding season, markedly dropped during the non-breeding season, and then showed a marked increase in pre-hibernation (Figure $3 \mathrm{C}, \mathrm{D}$ ). After obtaining the sequence of each PCR product, we blasted with the known mRNA sequences of rat, mouse, human and bovine, found the homologous sequence fragments in each species and compare for homology (Table 2).
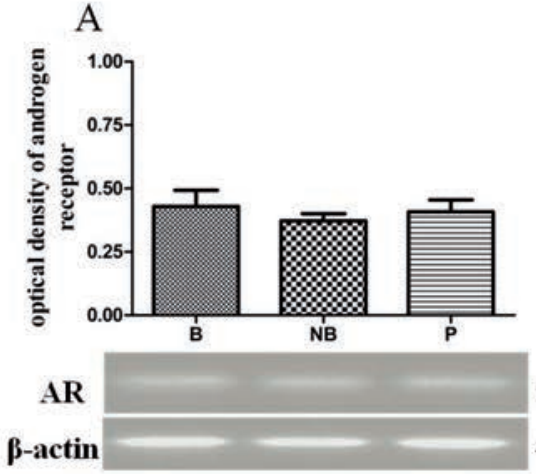

$101 \mathrm{kD}$

$43 \mathrm{kD}$

C
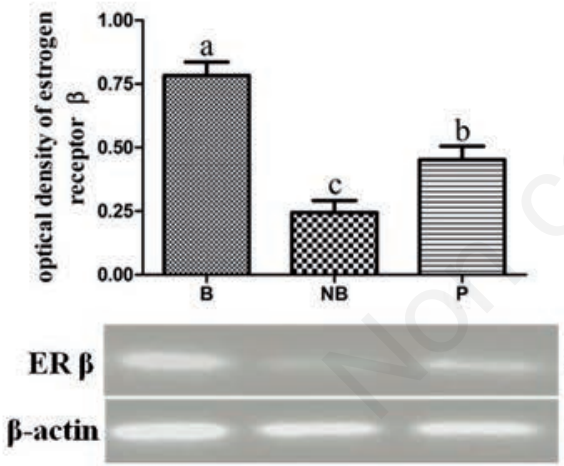

$59 \mathrm{kD}$ $43 \mathrm{kD}$

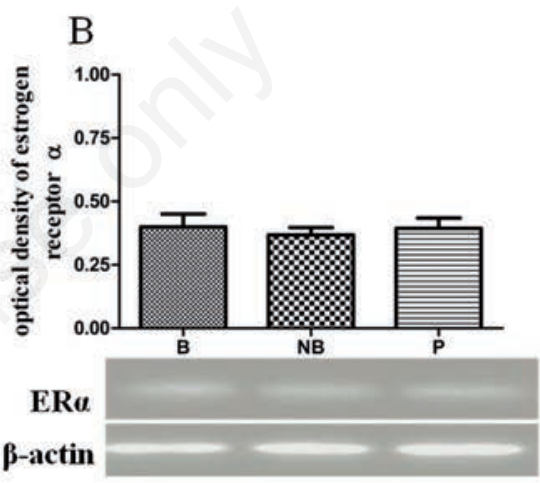

$66 \mathrm{kD}$

$43 \mathrm{kD}$
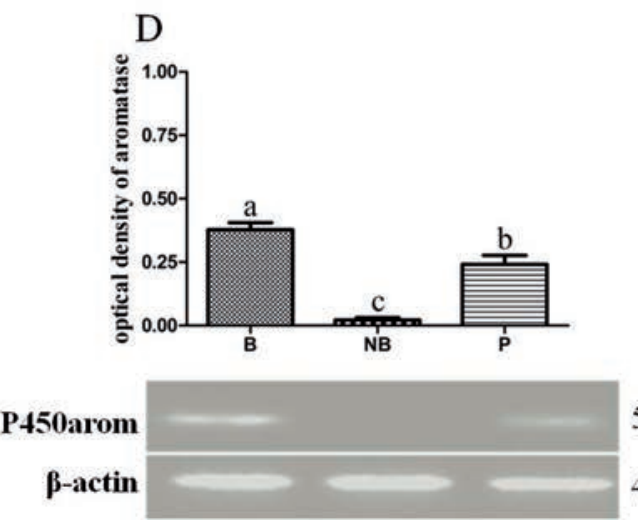

$55 \mathrm{kD}$

$43 \mathrm{kD}$

Figure 2. Western blot analysis of the protein level of AR, ER $\alpha, E R \beta$ and P450arom during the annual cycle. The expressions of AR (A), ER $\alpha$ (B), ER $\beta$ (C) and P450arom (D) showed the changes during the breeding season, the non-breeding season and pre-hibernation. $B$, the breeding season; NB, the non-breeding season; $\mathrm{P}$, pre-hibernation. Bars represent means \pm SD for five independent experiments. Means within the columns marked with different letters indicate significant difference $(\mathrm{P}<0.05)$.

Table 2. Nucleotide sequence identity in testis of wild ground squirrel in comparison with rat, mouse, human and bovine.

\begin{tabular}{lcccc} 
& Rat (\%) & Mouse (\%) & Human (\%) & Bovine (\%) \\
AR & 91.35 & 90.12 & 92.31 & 90.12 \\
ER alpha & 85.50 & 86.68 & 89.05 & 89.34 \\
\hline ER beta & 93.54 & 92.74 & 87.91 & 84.68 \\
CYP19 & 78.77 & 81.01 & 82.12 & 83.05 \\
\hline Beta-actin & 90.01 & 91.16 & 88.37 & 83.62 \\
\hline
\end{tabular}




\section{Discussion}

This was the first study to investigate the expression of AR, ERa, ERb and P450arom in the MPOA of the wild male ground squirrels, which clearly demonstrated the presence of $\mathrm{AR}, \mathrm{ERa}, \mathrm{ERb}$ and P450arom in the MPOA of this wild rodent during the breeding season, the non-breeding season and pre-hibernation. These findings strongly suggested that the hypothalamic MPOA may be a direct target of androgens and estrogens; and estrogens may play important regulatory roles in hypothalamic function in an autocrine/paracrine manner in this species.

The MPOA is a well-known androgenresponsive region that regulates homeostasis, neuroendocrinology and instinctive behavioral systems. ${ }^{33}$ Androgens play a pivotal role in the regulation of male sexual behaviors and aggressive behavior at least via AR in the MPOA and anterior hypothalamic areas. ${ }^{34,35}$ Previous studies showed that the expression levels of AR in the MPOA varied between differ- ent rodents. ${ }^{36}$ For example, AR expression in the mouse brain was shown to be much stronger than that of the rat brain, which may explain some of the behavioral differences. ${ }^{36}$ As a typical seasonal breeder, the wild ground squirrel exhibits distinct reproductive behavior from season to season. However, we observed a stably high AR expression in the MPOA throughout all seasons. A previous study in Siberian hamster linked photoperiod and the action of androgens, where they also showed that day length fluctuations could induce the expression of AR and steroid receptor coactivator- $1 .^{37}$ Therefore, the little change in day length (13-15 h) from the breeding season to pre-hibernation in latitudes (N41 14 '33"-41 56 '55") where the wild ground squirrels habitate may be a possible explanation. On the other hand, the stably strong expression may highlight the indispensable role of AR in normal hypothalamic function maintenance.

P450arom, an enzyme converting the androgens to estrogens, has been found in many tissues, including non-reproductive organs in male. ${ }^{22-24}$ In this study, we profiled the seasonal expressions of P450arom in the MPOA of the wild male ground squirrels, where highest protein and mRNA levels of P450arom were observed in the breeding season. The expression of P450arom in brain was shown to be a critical step for maintaining the male sexual behavior. ${ }^{38}$ Male mice with P450arom knockout in brain exhibited decreased fertility and reduced male sexual behavior. ${ }^{38}$ In several birds studied, P450arom mRNA in the MPOA of the non-breeding season was significantly lower than that of the breeding season.,22 For example, in the free-living male song sparrow (Melospiza melodia morphna), P450arom mRNA expression in the MPOA was higher during breeding season than non-breeding season or molt, which may be owing to the involvement of these brain areas in estrogendependent regulation of male sexual behavior. ${ }^{22,39}$ Interestingly, in pre-hibernation, P450arom activity in testes had a slight increase, which may be related to the change of reproductive status in this species. Our previous study in the wild ground squirrel
A
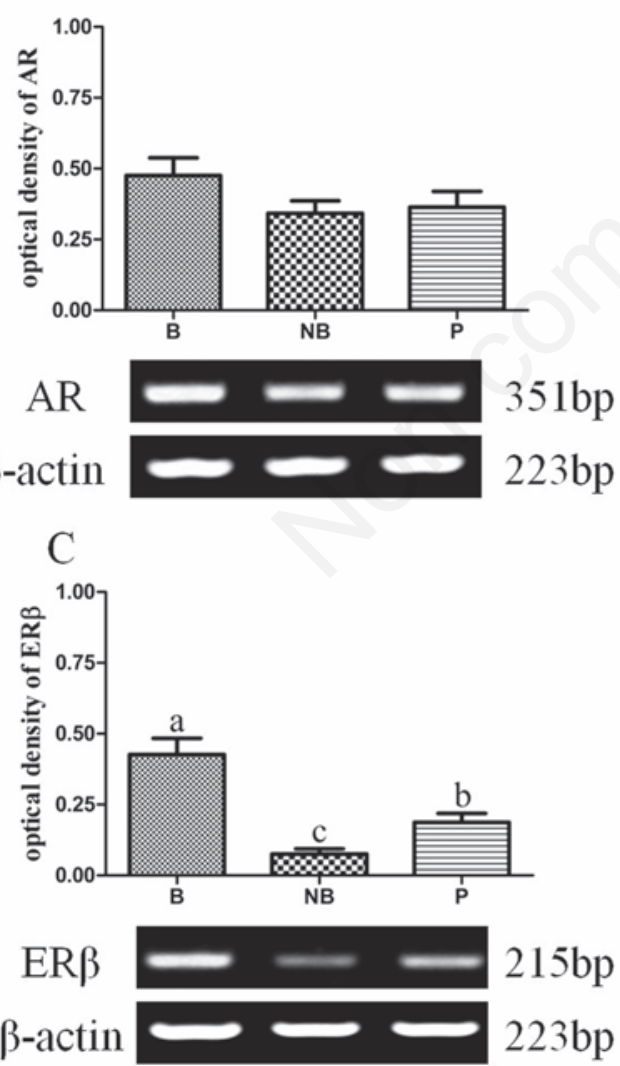

B
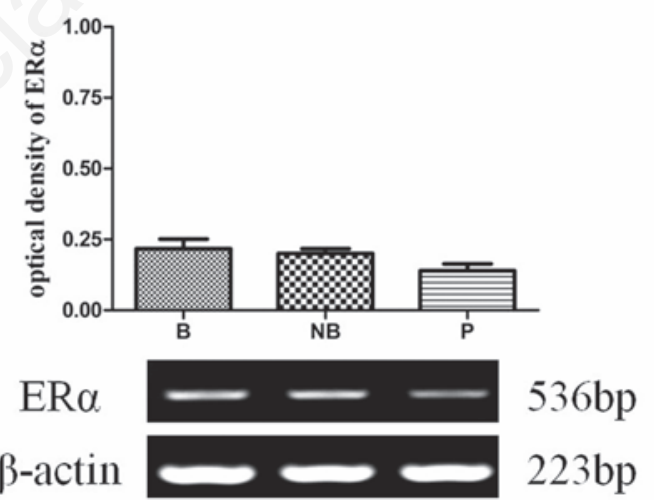

$\mathrm{D}$
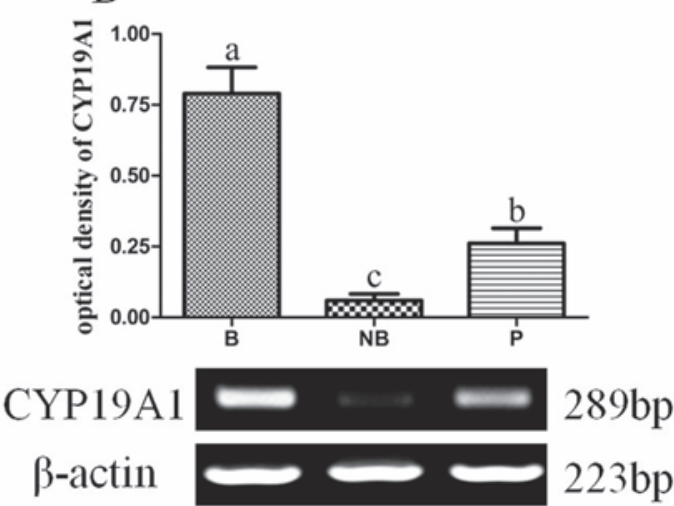

Figure 3. RT-PCR analysis of the $m R N A$ level of $A R, E R \alpha, E R \beta$ and P450arom during the annual cycle. The expressions of genes $A R$ (A), $E R \alpha(B), E R \beta$ (C) and $C Y P 19$ (D) showed the changes during the breeding season, the non-breeding season and pre-hibernation. $B$, the breeding season; NB, the non-breeding season; P, pre-hibernation. Bars represent means \pm SD for five independent experiments. Means within the columns marked with different letters indicate significant difference $(\mathrm{P}<0.05)$. 
revealed a testicular recrudescence during pre-hibernation, and P450arom mRNA and protein levels were concomitantly elevated relative to the non-breeding season. ${ }^{25}$ The present study showed that P450arom immunoreactivity in the MPOA was positively correlated with reproductive status, suggesting that local aromatization of androgens may be required for the seasonal function of the MPOA neurons.

ER $\alpha$ and ER $\beta$ are encoded by separate genes in the male reproductive tract or nonreproductive organs. ${ }^{40-42}$ Both ER $\alpha$ and ER $\beta$ have been observed in neurons and glia in the brain, and both are expressed throughout the brain with distinct patterns in different brain regions and with differing levels of expression during development. ${ }^{43}$ The present results showed that the expression level of ER $\alpha$ remained high throughout all periods, whereas ER $\beta$ showed higher immunoreactivity during the breeding season and pre-hibernation compared to the non-breeding season. These findings suggested that the MPOA of hypothalamus may be a direct target of estrogen. Previous studies have reported the relationship between the expression of ER $\alpha$ and ER $\beta$ in the MPOA and sexual behavior in some seasonally breeding avian species. However, the seasonal changes of ER $\alpha$ and ER $\beta$ are often modest and inconsistent across studies. For instance, there was no detectable seasonal change in either ER $\alpha$ or ER $\beta$ mRNA expression in the MPOA of male song sparrow. ${ }^{22}$ In contrast, the expression of ER $\alpha$ in the MPOA was elevated in the non-breeding season in male tropical spotted antbirds (Hylophylax naevioides).$^{44}$ In addition, Gonzales et al. have shown that ER $\beta$ may act as an inhibitor of ER $\alpha$ transcriptional activity in the developing rat ventromedial nucleus of the hypothalamus. ${ }^{45}$ The discrepancies may imply a species-specific effect, while the present data in a wild rodent further add up to the complex roles of ERs in brain physiology. Whatsoever, in this case the varied expression of ER $\alpha$ and ER $\beta$ may indicate differential roles in modulating the cyclic changes in hypothalamic function, which need to be further characterized.

In summary, our results demonstrated that $\mathrm{AR}, \mathrm{ER} \alpha, \mathrm{ER} \beta$ and P450arom were present in the MPOA of the wild male ground squirrels. Both the protein and mRNA expressions of P450arom and ER $\beta$ were higher in the breeding season and pre-hibernation than the nonbreeding season. These findings provide novel evidence implicating potentially critical roles of steroid hormones in regulating the hypothalamic function of a wild seasonally-breeding rodent.

\section{References}

1. Arnold AP, Gorski RA. Gonadal steroid induction of structural sex differences in the central nervous system. Annu Rev Neurosci 1984;7:413-42.

2. Palvimo JJ. The androgen receptor. Mol Cell Endocrinol 2012;352:1-3.

3. Fusani L, Van't Hof T, Hutchison JB, Gahr M. Seasonal expression of androgen receptors, estrogen receptors, and aromatase in the canary brain in relation to circulating androgens and estrogens. J Neurobiol 2000;43:254-68.

4. Czajka-Oraniec I, Simpson ER. Aromatase research and its clinical significance. Endokrynol Pol 2010;61:126-34.

5. Roselli CF. Brain aromatase: roles in reproduction and neuroprotection. J Steroid Biochem Mol Biol 2007;106:143-50.

6. Bulun SE, Mahendroo MS, Simpson ER. Aromatase gene expression in adipose tissue: relationship to breast cancer. J Steroid Biochem Mol Biol 1994;49:319-26.

7. Sasano H, Murakami H. Immunolocalization of aromatase in human breast disorders using different antibodies. Breast Cancer Res Treat 1998;49:S109-19.

8. Inoue T, Miki Y, Abe K, Hatori M, Hosaka M, Kariya Y, et al. Sex steroid synthesis in human skin in situ: the roles of aromatase and steroidogenic acute regulatory protein in the homeostasis of human skin. Mol Cell Endocrino. 2012;362:19-28.

9. Balthazart J. Steroid control and sexual differentiation of brain aromatase. J Steroid Biochem Mol Biol 1997;61:323-39.

10. Garcia-Segura LM. Aromatase in the brain: not just for reproduction anymore. J Neuroendocrinol 2008;20:705-12.

11. Green S, Walter P, Kumar V, Krust A, Bornert JM, Argos P, et al. Human oestrogen receptor cDNA: sequence, expression and homology to v-erb-A. Nature 1986;320:134-9.

12. Kuiper GG, Enmark E, Pelto-Huikko M, Nilsson S, Gustafsson JA. Cloning of a novel receptor expressed in rat prostate and ovary. Proc Natl Acad Sci USA 1996;93:5925-30.

13. Hughes ZA, Liu F, Marquis K, Muniz L, Pangalos MN, Ring RH, et al. Estrogen receptor neurobiology and its potential for translation into broad spectrum therapeutics for CNS disorders. Curr Mol Pharmacol 2009;2:215-36.

14. Xiao J, Wang NL, Sun B, Cai GP. Estrogen receptor mediates the effects of pseudoprotodiocsin on adipogenesis in 3T3-L1 cells. Am J Physiol Cell Physiol 2010; 299:28.

15. Shughrue PJ, Lane MV, Merchenthaler I.
Comparative distribution of estrogen receptor-alpha and -beta mRNA in the rat central nervous system. J Comp Neurol 1997;388:507-25.

16. Voigt $\mathrm{C}$, Gahr M, Leitner S, Lutermann H, Bennett N. Breeding status and social environment differentially affect the expression of sex steroid receptor and aromatase mRNA in the brain of female Damaraland mole-rats. Front Zool. 2014;11:1742-9994.

17. Simerly RB, Chang C, Muramatsu M, Swanson LW. Distribution of androgen and estrogen receptor mRNA-containing cells in the rat brain: an in situ hybridization study. J Comp Neurol. 1990;294:76-95.

18. Roselli CE, Horton LE, Resko JA. Distribution and regulation of aromatase activity in the rat hypothalamus and limbic system. Endocrinology. 1985;117:2471-7.

19. Hull, E.M., Rodriguez-Manzo, G. Male sexual behavior. 2nd ed. Pfaff, D.W., editors. Amsterdam: Elsevier Press; 2009.

20. Hull, E.M., Meisel, R.L., Sachs, B.D. Male sexual behavior. Pfaff, D.W., Arnold, A.P., Etgen, A.M., et al., editors. San Diego: Academic Press; 2002.

21. Compaan JC, Wozniak A, De Ruiter AJ, Koolhaas JM, Hutchison JB. Aromatase activity in the preoptic area differs between aggressive and nonaggressive male house mice. Brain Res Bull 1994;35:1-7.

22. Wacker DW, Wingfield JC, Davis JE, Meddle SL. Seasonal changes in aromatase and androgen receptor, but not estrogen receptor mRNA expression in the brain of the free-living male song sparrow, Melospiza melodia morphna. J Comp Neurol 2010;518:3819-35.

23. Krohmer RW, Boyle MH, Lutterschmidt DI, Mason RT. Seasonal aromatase activity in the brain of the male red-sided garter snake. Horm Behav 2010;58:485-92.

24. Hallgren SL, Linderoth M, Olsen KH. Inhibition of cytochrome p450 brain aromatase reduces two male specific sexual behaviours in the male Endler guppy (Poecilia reticulata). Gen Comp Endocrinol 2006;147:323-8.

25. Li Q, Zhang F, Zhang S, Sheng X, Han Y, Yuan Z, et al. Seasonal expression of androgen receptor, aromatase, and estrogen receptor alpha and beta in the testis of the wild ground squirrel (Citellus Dauricus Brandt). Eur J Histochem 2015; 59:2456.

26. Zhang H, Sheng X, Hu X, Li X, Xu H, Zhang $M$, et al. Seasonal changes in spermatogenesis and immunolocalization of cytochrome P450 17alphahydroxylase/c17-20 lyase and cytochrome P450 aromatase in the wild male ground 
squirrel (Citellus dauricus Brandt). J Reprod Dev 2010;56:297-302.

27. Zhang H, Wang Y, Zhang J, Wang L, Li Q, Sheng $\mathrm{X}$, et al. Testicular expression of NGF, TrkA and p75 during seasonal spermatogenesis of the wild ground squirrel (Citellus dauricus Brandt). Eur $\mathrm{J}$ Histochem 2015;59:2522.

28. Graham MD, Gardner Gregory J, Hussain D, Brake WG, Pfaus JG. Ovarian steroids alter dopamine receptor populations in the medial preoptic area of female rats: implications for sexual motivation, desire, and behaviour. Eur J Neurosci 2015;42:3138-48.

29. Paxinos G, Watson C. The rat brain in stereotaxic coordinates. 6 ed. Sydney, Academic Press: 2006.

30. Li X, Zhang H, Sheng X, Li B, Zhou J, Xu M, et al. Immunoreactivities of androgen receptor, estrogen receptors, p450arom, p450c17 proteins in wild ground squirrels ovaries during the nonbreeding and breeding seasons. J Ovarian Res 2012;5:17572215.

31. Budwit-Novotny DA, McCarty KS, Cox EB, Soper JT, Mutch DG, Creasman WT, et al. Immunohistochemical analyses of estrogen receptor in endometrial adenocarcinoma using a monoclonal antibody. Cancer Res 1986;46:5419-25.

32. Rizzardi AE, Johnson AT, Vogel RI, Pambuccian SE, Henriksen J, Skubitz AP, et al. Quantitative comparison of immunohistochemical staining measured by digital image analysis versus pathologist visu- al scoring. Diagn Pathol 2012;7:1746-596.

33. Mathieson WB, Taylor SW, Marshall M, Neumann PE. Strain and sex differences in the morphology of the medial preoptic nucleus of mice. $\mathrm{J}$ Comp Neurol 2000;428:254-65.

34. Harding SM, McGinnis MY. Androgen receptor blockade in the MPOA or VMN: effects on male sociosexual behaviors. Physiol Behav 2004;81:671-80.

35. Swaney WT, Dubose BN, Curley JP, Champagne FA. Sexual experience affects reproductive behavior and preoptic androgen receptors in male mice. Horm Behav 2012;61:472-8.

36. Jahan MR, Kokubu K, Islam MN, Matsuo C, Yanai A, Wroblewski G, et al. Species differences in androgen receptor expression in the medial preoptic and anterior hypothalamic areas of adult male and female rodents. Neuroscience 2015;284:943-61.

37. Tetel MJ, Ungar TC, Hassan B, Bittman EL. Photoperiodic regulation of androgen receptor and steroid receptor coactivator-1 in Siberian hamster brain. Brain Res Mol Brain Res 2004;131:79-87.

38. Honda S, Harada N, Ito S, Takagi Y, Maeda S. Disruption of sexual behavior in male aromatase-deficient mice lacking exons 1 and 2 of the cyp 19 gene. Biochem Biophys Res Commun. 1998;252:445-9.

39. Balthazart J, Ball GF. Topography in the preoptic region: differential regulation of appetitive and consummatory male sexual behaviors. Front Neuroendocrinol
2007;28:161-78.

40. Brewster ME, Anderson WR, Pop E. Effect of sustained estradiol release in the intact male rat: correlation of estradiol serum levels with actions on body weight, serum testosterone, and peripheral androgendependent tissues. Physiol Beha. 1997;61: 225-9.

41. Simpson ER, Mahendroo MS, Means GD, Kilgore MW, Corbin CJ, Mendelson CR. Tissue-specific promoters regulate aromatase cytochrome P450 expression. Clin Chem 1993;39:317-24.

42. Lu L, Liu S, Li Q, Huang S, Bao L, Sheng X, et al. Seasonal expression of androgen receptor in scented gland of muskrat (Ondatra zibethicus). Gen Comp Endocrinol 2014;204:1-7.

43. Wilson ME, Westberry JM, Trout AL. Estrogen receptor-alpha gene expression in the cortex: sex differences during development and in adulthood. Horm Beha. 2011;59:353-7.

44. Canoine V, Fusani L, Schlinger B, Hau M. Low sex steroids, high steroid receptors: Increasing the sensitivity of the nonreproductive brain. Dev Neurobiol 2007;67:57-67.

45. Gonzales KL, Tetel MJ, Wagner CK. Estrogen receptor (ER) beta modulates ERalpha responses to estrogens in the developing rat ventromedial nucleus of the hypothalamus. Endocrinology 2008;149: 4615-21. 